\title{
Does The Unconditional Cash Transfer Program in South Africa Provide Support for Women After Child Birth? Barriers To Accessing The Child Support Grant Among Women in Informal Work in Durban, South Africa
}

Silondile Luthuli ( $\square$ luthulis@ukzn.ac.za )

University of KwaZulu-Natal

Lyn Haskins

University of KwaZulu-Natal

Sphindile Mapumulo

University of KwaZulu-Natal

Christiane Horwood

University of KwaZulu-Natal

\section{Research Article}

Keywords: Cash transfer, Child support grant, informal work, maternal health, child health, child development, South Africa, Africa

Posted Date: September 17th, 2021

DOI: https://doi.org/10.21203/rs.3.rs-871452/v1

License: (c) (1) This work is licensed under a Creative Commons Attribution 4.0 International License.

Read Full License

Version of Record: A version of this preprint was published at BMC Public Health on January 16th, 2022. See the published version at https://doi.org/10.1186/s12889-022-12503-7. 


\section{Abstract \\ Background}

The child support grant (CSG) is the largest unconditional cash transfer program in Africa and aims to alleviate poverty and improve child health and nutrition in low-income families in South Africa. Among informal working women, the CSG is an important source of income after childbirth when informal workers are unable to work, but reports suggest that women experience delays in accessing the CSG. We explore experiences and challenges accessing the CSG among informal workers in Durban, South Africa

\section{Methods}

We undertook a longitudinal mixed-methods cohort study. Women informal workers were recruited during pregnancy and followed-up for up to one year after the baby was born. Quantitative questionnaires and semi-structured in-depth interviews were used to collect data about women's plans for applying for the CSG, the application process, use of the CSG in the household, and household food insecurity. Interviews were conducted in IsiZulu by experienced researchers. Descriptive analysis of quantitative data used SPSS v26, and framework analysis using NVIVO v12.3 was used for qualitative analysis.

\section{Results}

Twenty-four informal working women were enrolled. The CSG received for older children was reported as an important and reliable source of income for mothers after childbirth. However, delays receiving the CSG for the new baby meant this support was unavailable to first-time mothers. The complex application process for the CSG required mothers to go to various government departments to complete the required documentation, often taking the baby with them. This was costly and time-consuming for mothers who were already vulnerable, and led to delays in obtaining CSG funds. Many women experienced moderate or severe food insecurity before and after the baby was born. As a result, some mothers had to return to work earlier than planned, disrupting childcare and breastfeeding.

\section{Conclusion}

Cash transfer programmes can effectively support low income households and improve outcomes for mothers and children. In South Africa there is a need for innovative approaches to streamline CSG applications, so women can access the funds immediately post-delivery to fill a resource gap and provide support at a vulnerable time for mothers and their children.

\section{Background}


Cash transfer (CT) programmes are a social protection strategy that has been adopted in increasing numbers of low and middle-income countries, to provide income and alleviate poverty in low income families and communities $[1,2]$. The key aim of CTs is to break the cycle of intergenerational poverty and invest in the human capital of poor families [2]. Cash transfers may be unconditional or have conditions attached, for example school attendance, antenatal clinic attendance or facility-based delivery [2-5]. Cash transfers have been shown to successfully improve household poverty, health, nutrition and education indicators $[1,6-8]$, but have so far failed to convincingly address gender inequalities $[2,9]$. CTs can be aimed at a variety of beneficiaries depending on the objectives of the programme, including school-going children, pregnant women, rural families and carers of children [10-12].

The Child Support Grant (CSG) in South Africa (SA) is one of the largest unconditional CTs in Africa, with over twelve million beneficiaries [13]. The CSG was established in 1998 with the aim of alleviating child poverty and improving health and development outcomes for children in poor communities $[14,15]$. This aim was later expanded to include improvement in school attendance among children who receive the CSG [16]. The grant is provided to mothers or child carers in low-income families, and provides support to children from birth until 18 years. Studies on the CSG over almost two decades have consistently demonstrated the benefits of the grant on child nutrition, development and school attendance $[17,18]$.

Food insecurity is common in SA, with an estimated $25 \%$ of the population living below the food poverty line and considered food insecure [19]. A high proportion of female-headed households means that women frequently take the primary responsibility as breadwinners, providing food and basic shelter for their children [20,21]. Child-bearing can have the effect of marginalising women, both by reducing income-earning capacity and increasing their financial burdens [22]. Almost all grant recipients are women [23], so the grant has the potential to empower women to care for their children [21]; and the CSG is an important source, sometimes the only source, of income for women in poor communities [15]. The CSG often has multiple uses within the household [24], but evidence suggests that a high proportion of the money is spent on food $[18,24]$, and receipt of the grant is associated with improved food consumption and dietary diversity among children [16, 21, 23] and improved household food security [25]. However, a recent review suggests that although food insecurity and hunger has improved among recipients, the grant is insufficient to entirely prevent food insecurity and malnutrition [25]. Further, there has been little improvement in child nutrition since introduction of the CSG, with continued high rates of stunting among South African children [25].

One-third of women workers in South Africa are informal workers. These are a vulnerable group with low paid, insecure jobs, no access to maternity protection, and high rates of food insecurity [26]. Studies among informally working women suggest that the CSG is an important additional source of income, with many informally working women relying on the CSG received for their older children for support immediately after childbirth [26-28]. As heads of households, women carry responsibilities for feeding and childcare, which has a negative impact on their ability to work and support their family. 
There is substantial evidence since the inception of the CSG that women face challenges with accessing the CSG $[14,17,18,23,29]$. In this paper, we focus on barriers to accessing the CSG among informally working women in Durban, South Africa and the effect this has on food security and vulnerability after childbirth.

\section{Methods}

The data presented in this paper forms part of a larger longitudinal mixed methods cohort study that explored the relationship between childcare and informal work. We followed-up pregnant informal workers from pregnancy until they returned to work or when the child reached the age of one year. Quantitative and qualitative data were collected through a series of interviews at different time points (Fig. 1). Study methods are further described elsewhere [27, 30].

\section{Study setting}

The study was conducted in two townships in Durban, KwaZulu-Natal (KZN). The Durban area is characterized by high rates of unemployment, poverty, and low income in the population [31]. Mothers and primary caregivers of children from low-income households are eligible to apply for the CSG of R420 (approx US\$30) which is paid monthly for each child from birth until the age of 18.

\section{Participants and Sampling}

A sample size of 20 participants was estimated as enough to reach data saturation, based on our previous experience conducting qualitative research. Twenty-four informal working women were enrolled in the cohort to allow for loss to follow-up over the extended period of follow up. Participants were recruited in the antenatal clinics at two primary health care clinics in the Durban area during their last trimester of pregnancy. Eligible participants were aged 18years or older, between 32 and 38 weeks pregnant, and were designated as informal workers according to the study definition. Women were excluded if they worked less than three days a week or had been in informal work for less than 6 months or were planning to leave the area before the child was 6 months old. All eligible participants were requested to participate and underwent a three-stage recruitment process before being formally enrolled in the cohort.

\section{Data collection}

We conducted a series of interviews over the one-year follow up period which included both quantitative questionnaires and qualitative in-depth interviews (IDIs). The data was collected at different time points as follows: pre-delivery, within 2 weeks post-delivery, before and after returning to work, and when the baby was left in childcare (Fig. 1). The quantitative data included demographic data and food insecurity at each time point using the Household Food Insecurity Access Scale (HFIAS) [32]. During IDIs, participants were asked about their plans and experiences of applying for the CSG. All interviews were conducted in IsiZulu by experienced researchers and were audio recorded. 


\section{Data analysis}

IDIs were transcribed verbatim and translated into English. Framework analysis using NVIVO v12.3 was used to analyse qualitative data. During qualitative analysis the team of researchers first familiarised themselves with the data and coded a sample of the data to develop a coding framework. The coding framework was finalised during a series of meetings with the research team. Quantitative data analysis used SPSSv26 and is presented as frequencies. Food insecurity was scored according to recommended HFIAS practices. HFIAS is a series of nine questions in which participants were asked about their access to food. If they indicated any lack of access to food, participants were asked to categorise it according to how often this happened (rarely, sometimes or often). Based on the answers participants gave, they were categorised using the HFIAS system as no/mild food insecurity, moderate food insecurity, or severe food insecurity.

Participants were considered severely food insecure if the experienced any of the three most severe conditions such as running out of food, going to be hungry or going a whole day and night without food, or if they have had to eat smaller meals or eat few meals in a day often. Participants were considered to be moderately food insecure if they were eating a monotonous diet often or sometimes, or by starting to cut down on the size of the meal rarely or sometimes. Participants were considered to have no or mild food insecurity if they have either none of the food insecurities or if they only worry about accessing food. No or mild food insecurity also includes if there are unable to eat their preferred foods, or if they eat a more monotonous diet or food considered undesirable rarely [33].

\section{Results}

Twenty-four informal working women were enrolled in the cohort during pregnancy, and 87 interviews were conducted with the women over the study period. These included 24 interviews at pre-delivery, 24 post-delivery, 18 pre-work, 18 after return-to-work, and four baby-in-care interviews (Fig. 1). The median age of participating informal workers was 28.5 years (SD 4.7; IQR 25.0-30.7) at the pre-delivery interview.

Among 24 participating mothers 18 mothers returned to work, three mothers lost their jobs and did not return to work and three mothers were lost to follow up before returning to work. Most informal workers (10) returned to work within two months of the birth of the baby. Sociodemographic characteristics are shown in Table 1. 
Table 1

Socio-demographic characteristics of participants

\begin{tabular}{|c|c|}
\hline & $\begin{array}{l}\text { All Women } \\
\mathrm{N}=24\end{array}$ \\
\hline \multicolumn{2}{|l|}{ Age } \\
\hline $18-25$ years & 6 \\
\hline $26-30$ years & 12 \\
\hline $31-35$ years & 4 \\
\hline 36 and over & 2 \\
\hline \multicolumn{2}{|l|}{ Education } \\
\hline Secondary school Grade 8-11 & 17 \\
\hline Completed school & 7 \\
\hline \multicolumn{2}{|l|}{ Current relationship status/family situation } \\
\hline Single & 1 \\
\hline Married & 1 \\
\hline In a relationship and living with partner & 13 \\
\hline In a relationship and not living with partner & 9 \\
\hline \multicolumn{2}{|l|}{ Number of other biological children (excluding current pregnancy) } \\
\hline First pregnancy & 4 \\
\hline 1 & 11 \\
\hline 2 & 5 \\
\hline 3 & 4 \\
\hline \multicolumn{2}{|l|}{ Monthly income } \\
\hline$\leq \mathrm{R} 1000(\leq \mathrm{US} \$ 72)$ & 6 \\
\hline R1000 -R3000 (US\$72 - US\$215) & 16 \\
\hline$\geq$ R3000 ( $\geq$ US\$215) & 2 \\
\hline Received financial contribution from partner during pregnancy & 22 \\
\hline \multicolumn{2}{|l|}{ Planned to take time off before childbirth } \\
\hline Yes & 4 \\
\hline No & 9 \\
\hline
\end{tabular}




\begin{tabular}{|ll|}
\hline & All Women \\
& $\mathbf{N}=\mathbf{2 4}$ \\
\hline Already stopped working at baseline & 11 \\
\hline
\end{tabular}

We found high rates of food insecurity at the pre-delivery interview that persisted until the return to work interview for some participants. Many informal workers reported moderate or severe food insecurity during the period before and after the birth of the baby (Table 2). However, mothers rarely discussed or mentioned that they sometimes had to miss meals.

Table 2

Food insecurity among participants at different time points

\begin{tabular}{|c|c|c|c|c|}
\hline & Defined as & $\begin{array}{l}\text { Pre- } \\
\text { delivery } \\
(\mathrm{N}= \\
24)\end{array}$ & $\begin{array}{l}\begin{array}{l}\text { Post- } \\
\text { delivery }\end{array} \\
(\mathrm{N}= \\
24)\end{array}$ & $\begin{array}{l}\text { Pre- } \\
\text { work } \\
(N= \\
\left(8^{*}\right)\end{array}$ \\
\hline $\begin{array}{l}\text { No or } \\
\text { mild food } \\
\text { insecurity } \\
\text { HFIAS } \\
\text { score }\end{array}$ & $\begin{array}{l}\text { Household members have access to sufficient food } \\
\text { nutritious food (food secure) or are sometimes limited in } \\
\text { diversity or preferred choices (mild food insecurity). }\end{array}$ & 6 & 10 & 10 \\
\hline $\begin{array}{l}\text { Moderate } \\
\text { food } \\
\text { insecurity }\end{array}$ & $\begin{array}{l}\text { Household members have access to lower quality food } \\
\text { and are sometimes limited either in number and/or size of } \\
\text { meals. }\end{array}$ & 10 & 7 & 4 \\
\hline $\begin{array}{l}\text { Severe } \\
\text { food } \\
\text { insecurity }\end{array}$ & $\begin{array}{l}\text { Household members often had to limit number or size of } \\
\text { meals and/or had no food }+/ \text { - gone to bed hungry. }\end{array}$ & 8 & 7 & 4 \\
\hline $\begin{array}{l}\text { *Three mo } \\
\text { returning t }\end{array}$ & $\begin{array}{l}\text { ers lost their jobs and did not return to work, three mothers } \\
\text { ork }\end{array}$ & ere lost tc & ollow-up & \\
\hline
\end{tabular}

... He (baby) eats food now - porridge, and I sometimes buy Nespray for him, like two packets - he eats that. If it is finished, it is finished because I do not have support from anyone. (M02_Did not return to work).

The women in our study relied heavily on the CSG to pay for food and basic household services, but they experienced multiple challenges in applying and accessing the CSG for newborn babies. This increased their vulnerability and, in some cases, led to food insecurity and early return to work. The findings are presented according to four main themes: sources of income while not working before and after 
childbirth, the role of the CSG in supporting the household, delays in receiving the CSG, and the impact of such delays.

\section{Sources of income during leave from work before and after childbirth}

Many women had stopped working in the last trimester of pregnancy, and relied mainly on the financial support from the father of the baby (19/24), and the CSG received for their older children (13/24) as sources of income while not working. The CSG was often the only consistent and reliable source of income during this period, because other income sources were insecure and varied according to circumstances, for example the father's income or other financial commitments of family members. However, most women made plans to apply for the CSG as soon as the baby was born as an additional source of income.

I hope I can register him for a child support grant because I cannot rely on his father because he is not supporting me even now. I will apply for a child support grant for him and then I will see when he is older if I can go back to (informal) work while (I am) looking for another job that will pay me better (M02_Baseline).

\section{The Importance Of Csg In Supporting The Household}

Even when she was working women's income from informal work was often unpredictable, so the CSG was important as a reliable income source to provide for essentials. In particular, while the mother was not working before and after the birth of her child, the CSG received for older children was vital in providing for household and baby needs. However, delays in receiving the CSG meant that the CSG for the newborn baby was not available in the early weeks of the child's life, and for first time mothers the CSG was not available until the application was complete, so they did not have support after the baby was born.

I depend on the child support grant but I have not yet registered for her (new baby). I have the child support grant for the other 2 children ... There are a lot of us here at home and we contribute R500 a month...so we can buy food. I am going to have a problem next month because I have to contribute $R 500$ for [food]; perhaps I have to buy nappies... since I am not working it is tough; it is going to be tough. (M16_Post-delivery).

For some women, delays in receiving the CSG funds forced them to return to work early. The CSG money for older children was not enough for all the baby and household needs, leading to early return to work.

It was the financial circumstances [that made me go back to work]. The child needs nappies. We also need money in the house. We were relying on the child support grant money but it is insufficient. There are too many things that are needed. (M23_Return to work) 


\section{Delays In Receiving Csg}

At the end of the follow up period, ten participants had not applied for the CSG because of a variety of challenges (Table 3), and in one case because the mother was able to manage without the grant. A further four women had completed the application but had not yet received the grant and nine had received the grant. One mother was lost to follow-up before she applied for the grant. Among nine mothers who had received the grant, most had received it before the baby was 3 months old (7), others waited for more than 6 months (2). The four mothers who were still waiting for the grant had children aged between 2 and 11 months. 
Table 3

Challenges in applying for the CSG reported by the participants

\begin{tabular}{|c|c|c|c|c|}
\hline $\begin{array}{l}\text { SASSA } \\
\text { requirements for } \\
\text { CSG application }\end{array}$ & $\begin{array}{l}\text { Common } \\
\text { Challenges }\end{array}$ & $\begin{array}{l}\text { Process } \\
\text { required }\end{array}$ & $\begin{array}{l}\text { Participants } \\
\text { experiences }\end{array}$ & Participant example \\
\hline $\begin{array}{l}\text { IDENTITY (ID) } \\
\text { DOCUMENT for } \\
\text { mother } \\
\text { ID document and } \\
\text { proof of marriage } \\
\text { for married } \\
\text { applicants } \\
\text { Fathers ID for } \\
\text { applicants with } \\
\text { father's name on } \\
\text { child's birth } \\
\text { certificate }\end{array}$ & $\begin{array}{l}\text { o Applicant } \\
\text { has never had } \\
\text { an ID } \\
\text { o Missing or } \\
\text { lost ID/smart } \\
\text { card for } \\
\text { primary } \\
\text { caregiver } \\
\text { o Missing or } \\
\text { lost ID/smart } \\
\text { card for } \\
\text { spouse/child's } \\
\text { father }\end{array}$ & $\begin{array}{l}\text { First time } \\
\text { ID/smart card } \\
\text { applicants } \\
\text { must be } 16 \\
\text { years and } \\
\text { above, and } \\
\text { have a birth } \\
\text { certificate, } \\
\text { proof of } \\
\text { address and } \\
\text { must be } \\
\text { accompanied } \\
\text { by parent with } \\
\text { their own ID } \\
\text { book/smart } \\
\text { card for the } \\
\text { application. } \\
\\
\text { If applicant or } \\
\text { spouse/child's } \\
\text { father has lost } \\
\text { his ID/smart } \\
\text { card, they have } \\
\text { to go to Home } \\
\text { affairs to } \\
\text { apply for re- } \\
\text { issuing of the } \\
\text { document and } \\
\text { receive the } \\
\text { Temporary } \\
\text { Identification } \\
\text { Certificate } \\
\text { (TIC). The } \\
\text { application } \\
\text { process takes } \\
14 \text { working } \\
\text { days and the } \\
\text { TIC is } \\
\text { available } \\
\text { during that } \\
\text { time. }\end{array}$ & $\begin{array}{l}\text { Two } \\
\text { participants do } \\
\text { not have an ID } \\
\text { (M10 \& M15) } \\
\text { and one father } \\
\text { had no ID } \\
\text { (M05) }\end{array}$ & $\begin{array}{l}\text { No. I still have to apply } \\
\text { for an identity document } \\
\text {... then I can do a birth } \\
\text { certificate for the baby } \\
\text { and apply for a child } \\
\text { support grant for her } \\
\text { (M10_Post-delivery). } \\
\text { No, I have not yet applied } \\
\text { for it because her father } \\
\text { lost his identity book. So } \\
\text { we are still waiting for } \\
\text { her father to get a } \\
\text { replacement identity } \\
\text { document and then he } \\
\text { will go and apply with it } \\
\text { (M05_pre-work). }\end{array}$ \\
\hline
\end{tabular}




\begin{tabular}{|c|c|c|c|c|}
\hline $\begin{array}{l}\text { SASSA } \\
\text { requirements for } \\
\text { CSG application }\end{array}$ & $\begin{array}{l}\text { Common } \\
\text { Challenges }\end{array}$ & $\begin{array}{l}\text { Process } \\
\text { required }\end{array}$ & $\begin{array}{l}\text { Participants } \\
\text { experiences }\end{array}$ & Participant example \\
\hline $\begin{array}{l}\text { PROOF of } \\
\text { INCOME }\end{array}$ & $\begin{array}{l}\text { o Documents } \\
\text { unavailable } \\
\text { o Lack of } \\
\text { knowledge } \\
\text { about } \\
\text { application } \\
\text { and } \\
\text { documents } \\
\text { required } \\
\text { o Lack of } \\
\text { knowledge } \\
\text { about } \\
\text { application } \\
\text { procedures for } \\
\text { married } \\
\text { applicants } \\
\text { o Father does } \\
\text { provide } \\
\text { documents }\end{array}$ & $\begin{array}{l}\text { Applicants } \\
\text { must prove } \\
\text { they earn less } \\
\text { than R4000 } \\
\text { per month for } \\
\text { single } \\
\text { applicants or } \\
\text { R8000 per } \\
\text { month for } \\
\text { applicants } \\
\text { who are } \\
\text { married or in a } \\
\text { relationship. } \\
\text { This requires } \\
\text { bank account } \\
\text { statements } \\
\text { with the } \\
\text { application (3 } \\
\text { months). } \\
\text { If married or in } \\
\text { a relationship } \\
\text { with the father, } \\
\text { the applicant } \\
\text { needs to also } \\
\text { provide } \\
\text { father's bank } \\
\text { statements. }\end{array}$ & & $\begin{array}{l}\text { I went to the Grant Office } \\
\text { and they gave me forms } \\
\text { which I filled out and } \\
\text { took to the police station } \\
\text { to get them stamped. I } \\
\text { then returned the forms } \\
\text { and they asked for my } \\
\text { bank statement } \\
\text { (M14_Pre-work). } \\
\text { I have plans for it } \\
\text { [applying for CSG] but I } \\
\text { do not know if the } \\
\text { application will succeed } \\
\text { since I am married. They } \\
\text { will ask about the child's } \\
\text { father because usually } \\
\text { when you apply for a } \\
\text { child support grant the } \\
\text { assumption is that the } \\
\text { child's father is absent or } \\
\text { does not support the } \\
\text { child (Mo6_Post- } \\
\text { delivery). }\end{array}$ \\
\hline
\end{tabular}




\begin{tabular}{|c|c|c|c|c|}
\hline $\begin{array}{l}\text { SASSA } \\
\text { requirements for } \\
\text { CSG application }\end{array}$ & $\begin{array}{l}\text { Common } \\
\text { Challenges }\end{array}$ & $\begin{array}{l}\text { Process } \\
\text { required }\end{array}$ & $\begin{array}{l}\text { Participants } \\
\text { experiences }\end{array}$ & Participant example \\
\hline $\begin{array}{l}\text { PROOF OF } \\
\text { EMPLOYMENT } \\
\text { OR } \\
\text { UNEMPLOYMENT } \\
\text { LETTER from the } \\
\text { Department of } \\
\text { Labour for } \\
\text { applicant and } \\
\text { spouse/ father of } \\
\text { the baby }\end{array}$ & $\begin{array}{l}\text { o Incorrect } \\
\text { employment } \\
\text { status } \\
\text { registered on } \\
\text { the } \\
\text { Department of } \\
\text { Labour } \\
\text { system }\end{array}$ & $\begin{array}{l}\text { Applicants } \\
\text { need to } \\
\text { include pay } \\
\text { slips with the } \\
\text { application. } \\
\text { Single } \\
\text { caregivers: } \\
\text { need to earn } \\
\text { less than } \\
\text { R48 000 per } \\
\text { annum. } \\
\text { Married } \\
\text { caregivers or } \\
\text { those in a } \\
\text { relationship } \\
\text { with the father: } \\
\text { need to earn } \\
\text { less than } \\
\text { R96 000 per } \\
\text { annum as a } \\
\text { couple } \\
\text { If unemployed } \\
\text { or informally } \\
\text { employed, } \\
\text { applicants } \\
\text { need to } \\
\text { include a proof } \\
\text { of } \\
\text { unemployment } \\
\text { letter obtained } \\
\text { from the } \\
\text { Department of } \\
\text { Labour. }\end{array}$ & $\begin{array}{l}\text { Unable to } \\
\text { provide proof } \\
\text { of } \\
\text { unemployment } \\
\text { status despite } \\
\text { being } \\
\text { unemployed } \\
\text { (M04 \& M06) }\end{array}$ & $\begin{array}{l}\text { When I got to the } \\
\text { Department of Labour I } \\
\text { was told that where I } \\
\text { work I am registered as a } \\
\text { permanent employee ... } \\
\text { They gave me a letter } \\
\text { stating same. They said I } \\
\text { must take that letter back } \\
\text { to SASSA ... When I got } \\
\text { there the official said to } \\
\text { me "you are registered as } \\
\text { a permanent employee } \\
\text { and you earn a lot of } \\
\text { money, so you are not } \\
\text { eligible for a child } \\
\text { support grant"... I asked } \\
\text { her where I work. I } \\
\text { wanted her to tell me the } \\
\text { name of the company } \\
\text { that I work for. She said I } \\
\text { must go back to the } \\
\text { Department of Labour } \\
\text { because she was not } \\
\text { going to be able to give } \\
\text { me any information, } \\
\text { except what was written } \\
\text { on the letter... The official } \\
\text { had also told me that the } \\
\text { grant that I was receiving } \\
\text { for the other two children } \\
\text { will be stopped } \\
\text { (Mo4_Pre-work). }\end{array}$ \\
\hline
\end{tabular}




\begin{tabular}{|c|c|c|c|c|}
\hline $\begin{array}{l}\text { SASSA } \\
\text { requirements for } \\
\text { CSG application }\end{array}$ & $\begin{array}{l}\text { Common } \\
\text { Challenges }\end{array}$ & $\begin{array}{l}\text { Process } \\
\text { required }\end{array}$ & $\begin{array}{l}\text { Participants } \\
\text { experiences }\end{array}$ & Participant example \\
\hline $\begin{array}{l}\text { BIRTH } \\
\text { CERTIFICATE for } \\
\text { new baby and for } \\
\text { older children } \\
\text { who receive a } \\
\text { grant }\end{array}$ & $\begin{array}{l}\text { o Delayed } \\
\text { issuing of } \\
\text { birth } \\
\text { certificate. } \\
\text { o Home } \\
\text { affairs } \\
\text { systems } \\
\text { unreliable } \\
\text { o Applicant } \\
\text { not South } \\
\text { African } \\
\text { o Extra } \\
\text { traveling } \\
\text { costs to } \\
\text { retrieve birth } \\
\text { certificates of } \\
\text { older children }\end{array}$ & $\begin{array}{l}\text { Applicants } \\
\text { need to get a } \\
\text { letter from the } \\
\text { hospital } \\
\text { confirming the } \\
\text { birth of the } \\
\text { child. This is } \\
\text { taken to Home } \\
\text { Affairs } \\
\text { Department to } \\
\text { apply for a } \\
\text { birth } \\
\text { certificate. In } \\
\text { some instance } \\
\text { home affairs } \\
\text { offices are at } \\
\text { the hospital. }\end{array}$ & $\begin{array}{l}\text { Delayed birth } \\
\text { certificate } \\
\text { (M07, M22, } \\
\text { M18, M02) } \\
\text { M17 is not a } \\
\text { South African } \\
\text { citizen but the } \\
\text { father of the } \\
\text { child is South } \\
\text { African. They } \\
\text { both need to } \\
\text { do DNA test to } \\
\text { prove that they } \\
\text { are parents } \\
\text { before } \\
\text { applying for } \\
\text { birth } \\
\text { certificate. }\end{array}$ & $\begin{array}{l}\text { Her birth certificate has } \\
\text { not yet been issued. I } \\
\text { was at [name of hospital] } \\
\text { yesterday and they said I } \\
\text { must wait } 10 \text { days and } \\
\text { then go and collect it } \\
\text { from Home Affairs } \\
\text { (M21_Post-delivery). } \\
\text { they said you are not } \\
\text { from this country. But } \\
\text { father of the baby is } \\
\text { from this country so you } \\
\text { cannot [apply for birth } \\
\text { certificate], you supposed } \\
\text { to go to Addington to do } \\
\text { Identity test [DNA test]. } \\
\text { So identity test [DNA test] } \\
\text { for the us } 3 \text { of us is } 2.2 \\
\text { [R2 } 200], \text { father and child } \\
\text { is } 1.2 \text { [R } 1200] \text {... So the } \\
\text { father of the baby said } \\
\text { he is looking for the } \\
\text { money to go Addington } \\
\text { to do identity test [DNA } \\
\text { test] (M17_Return to } \\
\text { work) }\end{array}$ \\
\hline $\begin{array}{l}\text { SCHOOL } \\
\text { ATTENDANCE } \\
\text { CERTIFICATE for } \\
\text { older children } \\
\text { receiving a grant } \\
\text { aged between } 7 \\
\text { and } 18 \text { years old }\end{array}$ & $\begin{array}{l}\text { o Time and } \\
\text { travel costs to } \\
\text { retrieve school } \\
\text { attendance } \\
\text { certificates of } \\
\text { older children }\end{array}$ & $\begin{array}{l}\text { Applicants } \\
\text { must include } \\
\text { school } \\
\text { attendance } \\
\text { certificates of } \\
\text { all children } \\
\text { under her care } \\
\text { who are } \\
\text { receiving the } \\
\text { CSG as part of } \\
\text { the new } \\
\text { application. }\end{array}$ & $\begin{array}{l}\text { Has to go to } \\
\text { another } \\
\text { province to get } \\
\text { school } \\
\text { certificate for } \\
\text { older children } \\
\text { (M21 \& M24) }\end{array}$ & $\begin{array}{l}\text { Ok. I was going to apply } \\
\text { for it at home [Eastern } \\
\text { Cape]. The problem is } \\
\text { that they wanted a letter. } \\
\text { I have two children, right? } \\
\text { The one that is at home } \\
\text { goes to school. So now I } \\
\text { will go home and ask for } \\
\text { a letter from the school } \\
\text { and then apply for a } \\
\text { grant for the younger } \\
\text { child (M24_Return to } \\
\text { work). }\end{array}$ \\
\hline
\end{tabular}

The application process as described by the women was long, time consuming, complex, and required a lot of paperwork (Table 3). Women reported that they had to go through various offices and departments to get forms filled in and approvals for the application, and they often had to carry the baby with them. These trips incurred costs that placed additional financial pressure on vulnerable women. In addition, several mothers required the father to take time off to provide documents, leading to further delays, since this was outside of the mothers direct control. 
... It is such a stringent process. I have to go to the Department of Labour to look for a letter then go back to the hospital to sign; I have to get a letter from the hospital; then go to Home Affairs; it is so much work to go to SASSA; ... It costs a lot of money to go to all these places plus I have to carry the baby with me ... (M09_pre-work).

Some women lacked understanding of the processes involved in the application and did not prepare the documents or get missing documents re-issued in preparation for applying for the CSG and some did not know how to go about starting the application process.

No I do not even know where you register for that. Please tell me where do you go to register to apply for it? I am serious; I do not know where you apply for it (M08_Pre-work).

\section{The Effects Of Delays In The Csg Application}

Delays in the application process and receipt of CSG funds increased the vulnerability for women and their children. Women resorted to different coping strategies to address their lack of resources, these included borrowing money from family/neighbors and loan sharks, and others returned to work early.

I could not stay home any longer. Furthermore, in my line of work if I do not work I do not get money because there is no one that is paying me a salary. If I want to earn money I have to work. So, if I was going to stay home longer I would not have had any income. (M05_Return to work).

For some of these women, returning to work meant stopping the application process because taking time off work was unacceptable to employers, or time off work reduced the mother's income.

That thing takes time, and her birth certificate was delayed and I was about to return to work and would not have had time. Yeah, so if I had not returned to work I would be taking her to register [for CSG] (M07_Return to work).

\section{Discussion}

Cash transfer programmes have been implemented in many low- and middle- income countries globally, with wide-ranging benefits to education, nutrition, and health in poor communities [22,24] and positive redistributive effects [25]. In South Africa the constitution guarantees the right to access to sufficient food, social security and assistance for people who cannot support themselves and their dependants [34]. The CSG is a cornerstone of government poverty relief interventions. This study highlights the difficulties faced by informal workers in applying for the CSG and echoes the findings of several previous studies conducted since the inception of the CSG in $1998[17,18,23]$. The benefits of the CSG throughout childhood are well established, and the CSG is globally recognized as a hugely successful poverty relief programme $[35,36]$. However, the application process is time-consuming, expensive and lengthy, and deprives mothers and children of the benefits of the CSG at a time when they are most needy and 
vulnerable. Despite ongoing and continued evidence of the challenges women face in obtaining the grant timeously, our study suggests that no effective action has been taken.

The CSG has several benefits to children and families throughout the years of childhood, but alleviating hunger and household food insecurity is the most crucial. However, despite these benefits there has been little or no improvement in the prevalence of stunting among South African children in the years since CSG implementation. Stunting remains a major public health problem despite high uptake and widespread coverage of the CSG [25]. Our study provides some insights into possible reasons for this from the perspective of informal workers, simply that the grant is received too late when a major opportunity for improving child nutrition has already passed, given that the largest benefits to child health are accrued during the early nutrition period when children are most vulnerable [23].

Women in our study described severe hardships during the period before and after the birth of a new baby when they were unable to work while also experiencing the financial pressure of providing for a newborn. Women with older children relied on the CSG as the only stable, reliable income for the family but women having their first baby were frequently left with no financial support. The effect of the delay in receiving the CSG for many of our participants was poverty, household food insecurity and an early return to work. Among informal workers in our study early return to work disrupted breastfeeding or led to mothers stopping breastfeeding altogether, with the need to buy formula adding to mothers' financial pressures, as reported elsewhere [27]. In addition, early return to work reduced the time available to continue with the CSG application, which was therefore further delayed.

The early weeks of a child's life are the foundation of a healthy future. Breastfeeding is crucially important for lifelong health and development, and spending time with your baby to breastfeed is a once in a lifetime opportunity. Unless the mother receives the support she needs to stay at home and continue to breastfeed, this opportunity will be missed with lifelong consequences for the child's future achievements [37]. There is evidence that the greatest benefits of the CSG are shown among children whose carer received the grant while the child was still young $[23,37]$. We suggest that providing the CSG immediately after birth would fill a crucial resource gap for informal working women and other lowincome families, and could give these mothers the opportunity to breastfeed and provide for their family, giving the children the chance to thrive [18].

New systems required to achieve this are likely to have significant costs, but this should be seen in the context of the benefits. Improved health and cognitive development associated with good nutrition in early childhood will have long term economic benefits for the individual, for families and communities [23]. There will be immediate economic benefits for families who no longer have to undertake costly travel with a young baby to government offices to provide documentation. We argue that the economic and health benefits of improved systems for CSG applications would have long term economic as well as health benefits, that would outweigh any additional costs, in both the long and short term [23]. Further, we suggest that extending the current CSG into pregnancy to alleviate poverty also has proven benefits for 
pregnancy outcomes, leading to reduced maternal and child morbidity and mortality, and would also ensure that the grant is available immediately after delivery [22].

Even without extending the grant to pregnant women, applications could be initiated during pregnancy, and the application finalized at delivery, when the baby's birth certificate is issued. Innovative technologies are already available to support the application process. During the COVID-19 epidemic the government introduced an unemployment grant. To roll this out quickly the South African Social Service Agency (SASSA) employed technology which allowed applicants to access this grant using platforms such as WhatsApp, SASSA website, SASSA email address and a toll-free number. Despite some challenges, this system proved to be effective, and approximately 9.7 million people accessed the special COVID-19 relief grant. We propose that SASSA expand this system to every CSG applicant to save time and money for mothers, and ensure that mothers and newborns receive the support they need.

\section{Conclusion}

The CSG is a powerful tool for alleviating poverty and improving outcomes for the next generation of economically active South Africans but long delays deprive mothers and children of support at a crucial time. These delays are unnecessary since effective technologies exist to prevent them. We suggest that this is the time to harness new technologies to ensure that the CSG is available to mothers of newborns, and extended to pregnant women. This would provide support to the most vulnerable women and children when it is most needed, giving children a better start in life, with health and economic benefits that far outweigh the costs.

\section{Abbreviations}

CT

Cash transfers

CSG

Child Support Grant

HFIAS

Household Food Insecurity Access Scale

ID

South African identity document

IDI

In-depth interview

SA

South Africa

SASSA

South African Social Service Agency

\section{Declarations}




\section{Ethical approval and consent to participate}

Ethical approval was obtained from the University of KwaZulu-Natal Humanities and Social Sciences Research Ethics Committee (HSSREC) (HSS/0319/018), the KZN Department of Health (HRKM235/18) and the World Health Organisation Ethics Committee (ERC 0003101). All mothers provided written informed consent to participate in the study. All methods in the study were carried out in accordance with relevant ethical guidelines and regulations. To maintain anonymity and confidentiality, mothers were allocated a study number that was used throughout the study period instead of their names.

\section{Consent for publication}

Not applicable

\section{Availability of data and material}

All data, transcripts and study tools to support the findings of this study are available from the Centre for Rural Health and will be made available upon reasonable request from the principle investigator or corresponding author.

\section{Competing interest}

The authors declare that they have no competing interests.

\section{Funding}

The funding for this study was provided by the World Health Organization. The funders did not participate or play a role in the design of the study, data collection, data analysis or reporting of the results.

\section{Authors' contributions}

$\mathrm{CH}, \mathrm{SL}, \mathrm{LH}, \& \mathrm{SM}$ conceptualized the study. SL and SM collected the data and all the authors analysed the data. SL and $\mathrm{CH}$ wrote the first draft. SL, CH, LH, \& SM reviewed the manuscripts throughout the writing process. SL, CH, LH, \& SM read and approved the final manuscript.

\section{Acknowledgements}

The authors would like to thank all the participants for giving their time, and Dr Nigel Rollins from WHO Geneva, for his contribution to the study.

\section{References}

1. Ben Haman O: Conditional and unconditional cash transfer programs: the recent experiences around the world. International Journal of Research and Innovation in Social Science 2019, 3(1):210-219. 
2. Molyneux $M$, Thomson M: Cash transfers, gender equity and women's empowerment in Peru, Ecuador and Bolivia. Gender \& Development 2011, 19(2):195-212.

3. Powell-Jackson T, Morrison J, Tiwari S, Neupane BD, Costello AM: The experiences of districts in implementing a national incentive programme to promote safe delivery in Nepal. BMC health services research 2009, 9(1):1-11.

4. Lim SS, Dandona L, Hoisington JA, James SL, Hogan MC, Gakidou E: India's Janani Suraksha Yojana, a conditional cash transfer programme to increase births in health facilities: an impact evaluation. The Lancet 2010, 375(9730):2009-2023.

5. Sosa-Rubí SG, Walker D, Serván E, Bautista-Arredondo S: Learning effect of a conditional cash transfer programme on poor rural women's selection of delivery care in Mexico. Health policy and planning 2011, 26(6):496-507.

6. Paes-Sousa R, Santos LMP, Miazaki ÉS: Effects of a conditional cash transfer programme on child nutrition in Brazil. Bulletin of the World Health Organization 2011, 89:496-503.

7. Levy D, Ohls J: Evaluation of Jamaica's PATH conditional cash transfer programme. Journal of Development Effectiveness 2010, 2(4):421-441.

8. Briaux J, Martin-Prevel Y, Carles S, Fortin S, Kameli Y, Adubra L, Renk A, Agboka Y, Romedenne M, Mukantambara F: Evaluation of an unconditional cash transfer program targeting children's first1,000-days linear growth in rural Togo: A cluster-randomized controlled trial. PLoS medicine 2020, 17(11):e1003388.

9. Cherayi S, Jose JP: Empowerment and social inclusion of Muslim women: Towards a new conceptual model. Journal of rural studies 2016, 45:243-251.

10. Rawlings LB, Rubio GM: Evaluating the impact of conditional cash transfer programs. The World Bank Research Observer 2005, 20(1):29-55.

11. Prabhu KS, Sahay R, Roy R, Vinay C: Conditional cash transfer schemes for alleviating human poverty: Relevance for India. Discussion Paper, No 1 United Nations Development Programme (UNDP), India 2009.

12. Fiszbein A, Schady NR: Conditional cash transfers: reducing present and future poverty: World Bank Publications; 2009.

13. SASSA: BRANCH: STRATEGY AND BUSINESS DEVELOPMENT:TWELVETH STATISTICAL REPORT: PAYMENT SYSTEM MARCH 2021. 2021.

14. Zembe-Mkabile W, Doherty T, Sanders D, Jackson D: Child Support Grant access and receipt among 12-week-old infants in an urban township setting in South Africa. Global health action 2014, $7(1): 25310$.

15. Zembe-Mkabile W, Surender R, Sanders D, Jackson D, Doherty $T$ : The experience of cash transfers in alleviating childhood poverty in South Africa: mothers' experiences of the Child Support Grant. Global public health 2015, 10(7):834-851.

16. DSD, SASSA, UNICEF: The South African Child Support Grant Impact Assessment: Evidence from a survey of children, adolescents and their households. Pretoria: UNICEF South Africa 2012. 
17. Case A, Hosegood V, Lund F: The reach and impact of Child Support Grants: evidence from KwaZuluNatal. Development Southern Africa 2005, 22(4):467-482.

18. Delany A, Ismail Z, Graham L, Ramkissoon Y: Review of the child support grant: Uses, implementation and obstacles. Johannesburg: Community Agency for Social Enquiry 2008.

19. Stats S: Poverty trends in South Africa: An examination of absolute poverty between 2006 and 2015. Pretoria: statistics south Africa 2017.

20. Zembe-Mkabile W, Surender R, Sanders D, Swart R, Ramokolo V, Wright G, Doherty T: 'To be a woman is to make a plan': a qualitative study exploring mothers' experiences of the Child Support Grant in supporting children's diets and nutrition in South Africa. BMJ open 2018, 8(4).

21. Granlund S, Hochfeld T: 'That Child Support Grant Gives Me Powers'-Exploring Social and Relational Aspects of Cash Transfers in South Africa in Times of Livelihood Change. The Journal of Development Studies 2020, 56(6):1230-1244.

22. Chersich M, Luchters S, Blaauw D, Scorgie F, Kern E, Van den Heever A, Rees H, Peach E, Kharadi S, Fonn S: Safeguarding maternal and child health in South Africa by starting the Child Support Grant before birth: Design lessons from pregnancy support programmes in 27 countries. South African Medical Journal 2016, 106(12):1192-1210.

23. Aguero J, Carter M, Woolard I: The impact of unconditional cash transfers on nutrition: The South African Child Support Grant. 2006.

24. Coetzee M: Finding the Benefits: Estimating the Impact of The S outh A frican Child Support Grant. South African Journal of Economics 2013, 81(3):427-450.

25. Devereux $\mathrm{S}$, Waidler $\mathrm{J}$ : Why does malnutrition persist in South Africa despite social grants. Food security South Africa working paper series 2017(001).

26. Horwood C, Haskins L, Hinton R, Connolly C, Luthuli S, Rollins N: Addressing the interaction between food insecurity, depression risk and informal work: findings of a cross-sectional survey among informal women workers with young children in South Africa. BMC Womens Health 2021, 21(1):2.

27. Luthuli S, Haskins L, Mapumulo S, Rollins N, Horwood C: 'I decided to go back to work so I can afford to buy her formula': a longitudinal mixed-methods study to explore how women in informal work balance the competing demands of infant feeding and working to provide for their family. $B M C$ public health 2020, 20(1):1-15.

28. Horwood C, Haskins L, Alfers L, Masango-Muzindutsi Z, Dobson R, Rollins N: A descriptive study to explore working conditions and childcare practices among informal women workers in KwaZuluNatal, South Africa: identifying opportunities to support childcare for mothers in informal work. $B M C$ pediatrics 2019, 19(1):1-11.

29. Leibbrandt M, Woolard I, Finn A, Argent J: Trends in South African income distribution and poverty since the fall of apartheid. 2010.

30. Horwood C, Hinton R, Haskins L, Luthuli S, Mapumulo S, Rollins N: 'I can no longer do my work like how I used to: a mixed methods longitudinal cohort study exploring how informal working mothers 
balance the requirements of livelihood and safe childcare in South Africa. BMC Women's Health 2021, 21(1):1-15.

31. South African population census 2011 [http://www.statssa.gov.za/?page_id=993\&id=ethekwinimunicipality]

32. Castell GS, Rodrigo CP, de la Cruz JN, Bartrina JA: Household food insecurity access scale (HFIAS). Nutricion hospitalaria 2015, 31(3):272-278.

33. Coates J, Swindale A, Bilinsky P: Household Food Insecurity Access Scale (HFIAS) for measurement of food access: indicator guide: version 3. 2007.

34. The Constitution of the Republic of South Africa. In.; 1996.

35. DSD, SASSA, UNICEF: Removing barriers to accessing Child Grants: Progress in reducing exclusion from South Africa's Child Support Grant. Pretoria: UNICEF South Africa 2016.

36. Patel L, Knijn T, Van Wel F: Child support grants in South Africa: a pathway to women's empowerment and child well-being? Journal of social Policy 2015, 44(2):377-397.

37. Victora CG, Bahl R, Barros AJ, França GV, Horton S, Krasevec J, Murch S, Sankar MJ, Walker N, Rollins NC: Breastfeeding in the 21st century: epidemiology, mechanisms, and lifelong effect. The Lancet 2016, 387(10017):475-490.

\section{Figures}


ENROLLMENT

(32-38 weeks pregnant)

$$
(\mathrm{N}=24)
$$

- Baseline quantitative data:

PRE-DEUIVERY INTERVIEW

(within four weeks before delivery)

$(\mathrm{N}=24)$ socioeconomic data, feeding

and child care plans

-In-depth interview: feeding and child care plans

Quantitative data: - infant

POST-DELIVERY INTERVIEW

(within 2weeks after birth) $(\mathrm{N}=24)$

PRE-WORK INTERVIEW

(a week before returning to work)

$$
(\mathrm{N}=18)
$$

-Quantitative data: -

infant feeding, work and child care

In-depth interview:mothers experiences, plans and practices about infant feeding, childcare, and returning to work.
Lost to follow up $(n=3)$

Did not return to work ( $n=3$ )

\section{Figure 1}

\section{Cohort diagram}

